Historic, Archive Document

Do not assume content reflects current scientific knowledge, policies, or practices. 



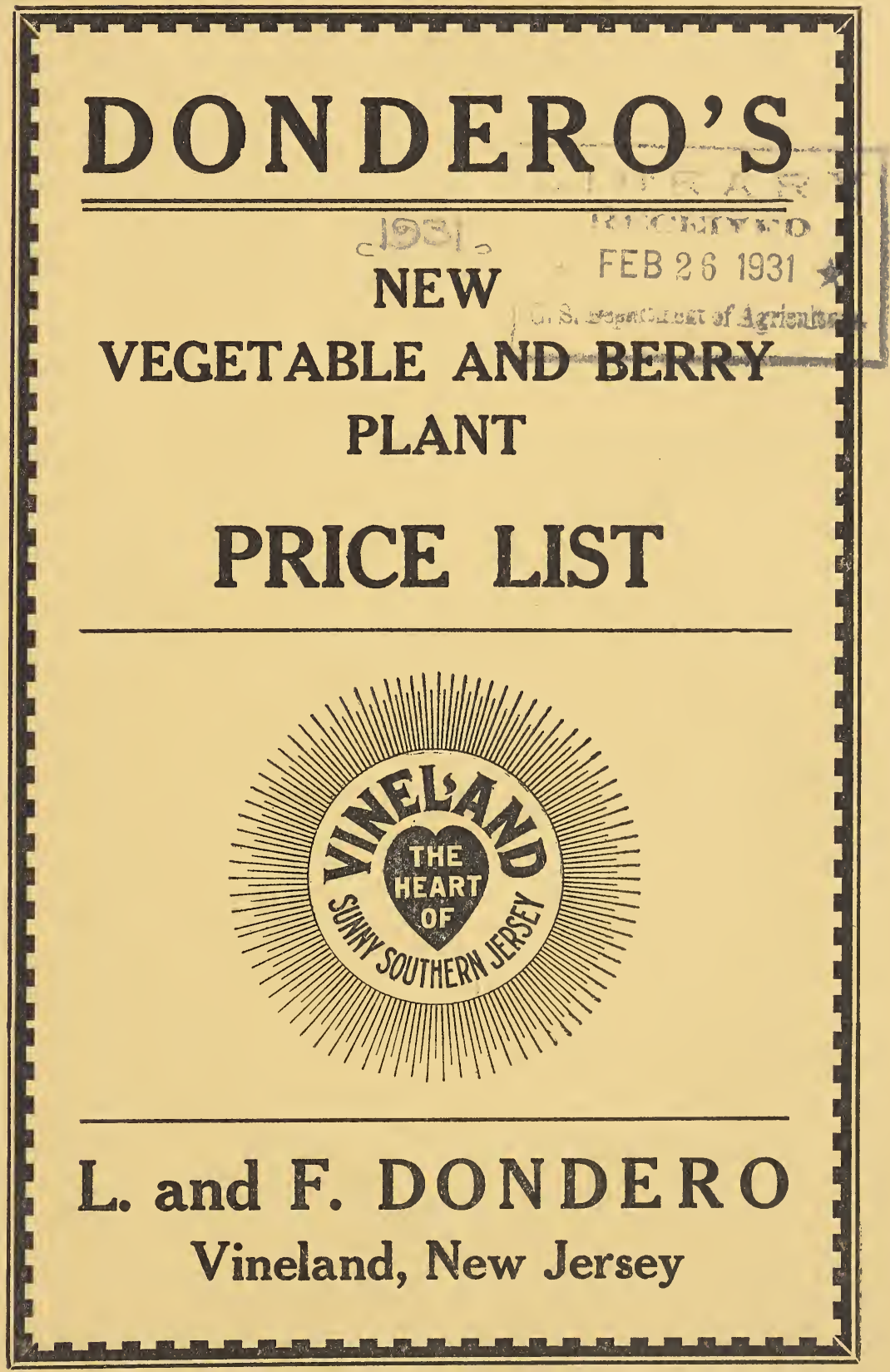




\section{Please Read This Page Carefully}

HOW TO ORDER. You should order just as soon as you receive this catalog. By so doing, you get your order booked in time before the rush of the season and get just what you want. Don't wait and be disappointed. You may add to your order later if you wish. Write name and address plainly and state how goods should be sent. When this is not done will use the best of our knowledge.

OUR TERMS. Cash with order. C. O. D. shipment will be made only when one-fourth amount is sent in with order. Kindly remit by Postal Money Order, Registered Letter, Express Money Order or Personal Check. Please do not ask us to open accounts for less than $\$ 10.00$ orders.

Packing is executed with utmost care. Special pains are taken to pack lightly, thereby reducing the expense of transportation to a minimum. There is no extra charge for packing.

GUARANTEE-We warrant our plants and seeds true to name, with the explicit understanding that should any prove otherwise, we will upon satisfactory proof, return the money paid or replace it with other stock; but we are not liable for damage beyond this. A sure indication of the purity of our stock and our way of doing business is the fact that custmers of former years continue to deal with us.

YOU WILL find the prices in this catalog much lower than others, for the kind of stock we are offering. A trial order will convince you that our plants are as good as can be purchased anywhere, regardless of cost.

CLAIMS, if any, must be made upon receipt of goods, when they will be carefully and cheerfully examined, and, if just, all will be made satisfactory. Claims made after five days from receipt of goods will not be entertained.

\section{OUR CATALOG INCLUDES THE FOLLOWING:}

$\begin{array}{lrlr} & \text { Page } & & \text { Page } \\ \text { Asparagus roots } & 4-5 & \text { Horseradish roots } & 19 \\ \text { Blackberry plants } & 7 & \text { Pepper plants } & 16 \\ \text { Brussels Sprouts plants } & 16 & \text { Raspberry plants } & 8 \\ \text { Cabbage plants } & 13 & \text { Rhubarb roots } & 19 \\ \text { Cauliflower plants } & 16 & \text { Strawberry plants } & 10 \\ \text { Dewberry, tip plants } & 9 & \text { Sweet Potato, Seed, Etc. } & 14 \\ \text { Egg Plant plants } & 13 & \text { Tomato plants } & 13 \\ \text { Grape Vines } & 6 & & \end{array}$

(Order blank inside back cover)

REFERENCES: First National Bank, Vineland, N. J.; Vineland Post Office. Any large business house in Vineland. 


\section{GREETINGS}

In issuing our Price-list for 1931, our first thought was to thank our many friends and customers for the confidence and patronage tendered our place last season. We enjoyed a large volume of business and trust our customers are as well pleased as we are.

Our next thought was to cut down expense in every way possible and pass the saving on to the customer. No elaborate catalog or anything unnecessary in any way. Retaining of course the same high-class and fully certified stock as in former years.

Finally we would offer our trade only the best stock at the very lowest price possible (practically everything has been reduced) with a true explanation in each case so they know exactly what they are getting and we will be able to continue our motto, "A Satisfied Customer or His Money Back."

Sincerely yours,

L. \& F. DONDERO

STATE OF NEW JERSEY
THE DEPARTMENT OF AGRICULTURE
Bureau of Statistics and Inspection
Trenton, N. J., September 1st, 1930.
No. $386 \quad$ That we have this 28th day of Aug.
THIS IS TO CERTIFY That
1930, in accordance with the provisions of Chapter. 268 Laws of
1916, State of New Jersey, inspected or caused to be inspected
by a duly appointed Inspector the GENERAL Nursery Stock
growing in the L. and F. Dondero Nursery of L. and F. Dondero,
proprietors, at Vineland in Cumberland County, New Jersey,
and have found the same apparently free from San Jose Scale
and other dangerously injurious insect pests and dingerously
destructive plant diseases.
This Certificate expires Sept. 1, 1931, and covers only stock
actually in the nurseries when examined.
(Signed) THOMAS J. HEADLEE,
WM. H. MARTIN, State Plant Pathologist.
RALPH B. LOTT, Chief Insp.

\section{SPECIAL RASPBERRY CERTIFICATE}

No. 4

Trenton, N. J.

THIS IS TO CERTIFY That the Raspberry plants from which sales are to be made by $\mathbf{L}$. and F. DONDERO of Vineland in Cumberland County during the season of 1930-1931, have been field inspected and found practically free from transmissible diseases.

October 7th, 1930.

EDGAR G. REX, Inspector 


\section{ASPARAGUS ROOTS}

THE MARY WASHINGTON

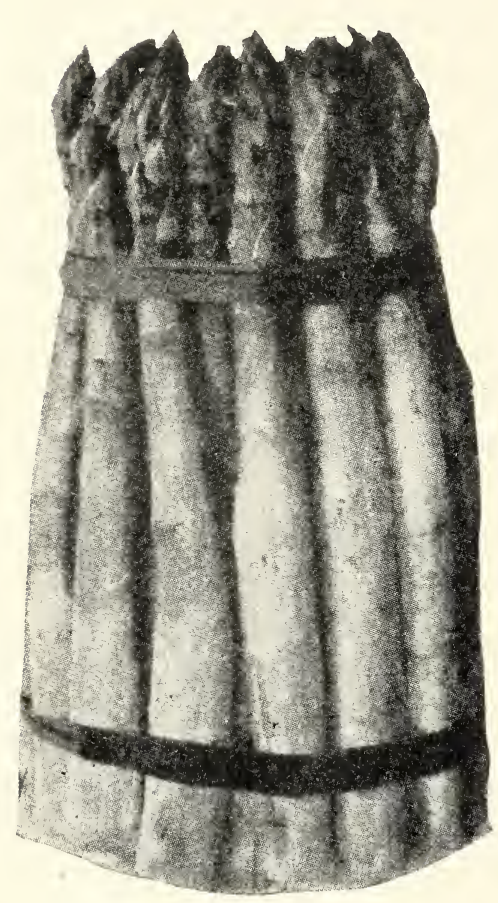

planter.

Roots are ordinarily shipped about last week in March. Orders should be placed as soon as possible. At the following prices every family should have its own Asparagus bed.

\begin{tabular}{|c|c|c|c|c|}
\hline PRICES & 50 & 100 & 500 & 1000 \\
\hline 1 year No. 1 & $\$ .60$ & $\$ .90$ & $\$ 3.50$ & $\$ 5.50$ \\
\hline 2 year No. 1 & .90 & 1.50 & 5.50 & 9.00 \\
\hline 2 year No. 2 & .60 & .90 & 3.50 & 5.50 \\
\hline year No. 1 (Heavy) & 1.50 & 2.50 & 8.00 & \\
\hline
\end{tabular}

Postpaid, 500 or less; more than 500 charges collect.

Altho the above prices may seem too low to some customers, we guarantee to send you the variety and size as ordered. Growing Asparagus roots for 5 of the largest seed houses in the East and selling upward of 200,000 annually is reason enough for our low prices. Write for special prices on quantity lots, stating how many you can use.

For proper culture, see opposite page. 


\title{
The Washington
}

\author{
Another good variety
}

In short the Washington is exceptionally rust-resistant due to unusually vigorous constitution (secured by critical selection extending over ten years); extraordinary yielding qualities; large size, of individual stialks and their rapid development to cutting size, which rapid growth stands for tenderness. The shoots are straight, of dark green color, with a heavy purple overtone. They do not open until well above the ground.

PRICES: Bottom of page.

PALMETTO (True) - Bears stalks of large size, is of early maturity, and a heavy yield. A very reliable variety that is comparatively free from rust and blight.

\section{PRICES: Bottom of page.}

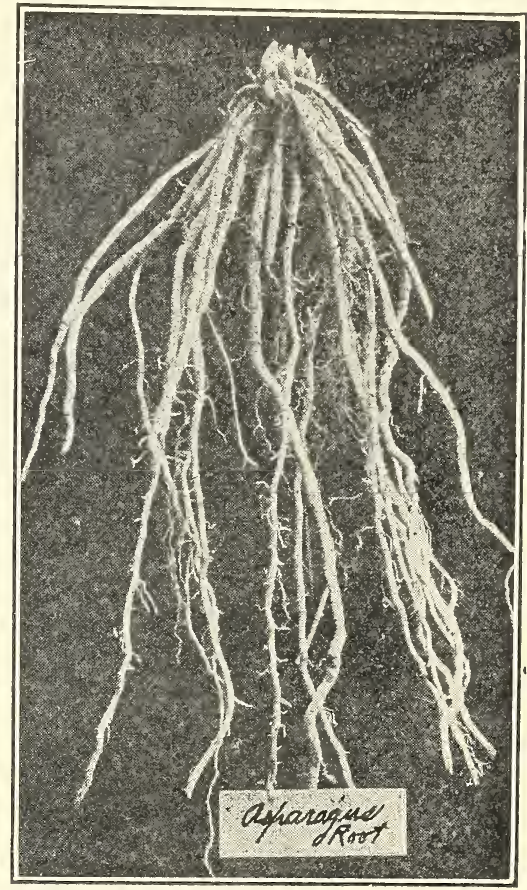

CULTURE: Select good loamy soil that is well drained. Plow out rows 4 feet apart going down about 7 inches. Put quantity of stablel manure down first then cover a little with top soil. Place the roots down with crown up spreading the roots out carefully about 18 inches (for small garden) or 24 inches for field planting. Cover to a depth of about 2 inches and as they grow through, gradually increase to 6 inches. DO NOT use commercial fertilizer or bird manure down on the roots. Either of these can be used on top of the ground when roots are covered over five inches.

At the above rate 100 plants require a plot about $12 \times 40$. It takes about 5000 roots to plant an acre.

PRICES

1 year No. 1

2 year No. 1

2 year No. 2

3 year (Extra Heavy)
50

$\$ .50$
.75
.50
1.25

1.25
100

500

1000

$\$ 5.00$

7.00

1.25

.75

2.00
$\$ 3.00$

4.50

3.00

7.00

500 or less sent postpaid; larger lots sent as directed, charges collect. 


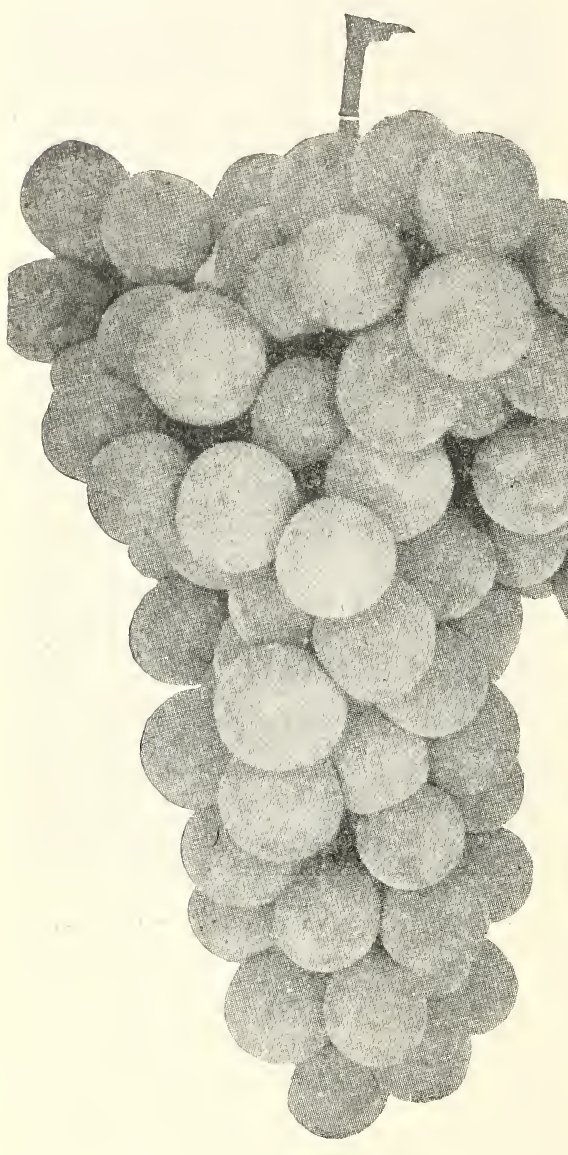

\section{Standard Varie- ties of Grapes}

The Pick of the Choicest!

The grape is one of the easiest of cultivation, growing amost anywhere and requiring very little attention. They can be grown on a trellis or the vine's trailed 'along a fence, and they are also grown for shade for the back porch or summer house, not only giving protection from the sun, but producing in autumn an abundance of fruit, thus giving a two-fold return.

Plant 5 feet apart.

CATAWBA-This we recommend as the best of all red grapes. The bunches are large and very compact. Very good for the table use, also for jelly or wine.

CONCORD (Black) - The leading variety for home use, producing large bunches of big black fruit of splendid flavor. A good keeper and excellent for making grape juice. By far the most popular grape on the market.

NIAGARA (White)-The standard white grape. Both bunch and berries are large handsome and well formed. The flesh is firm and juicy, while the flavor is of the best. A splendid variety in every way, and should be in every collection.

\section{PRICES}

Concord 1 year (Well rooted)

Concord 2 year (Well rooted)

Concord 3 year (Extra heavy)

Catawba 2 year (Heavy plants)

Niagara 2 year (Well rooted)
12

$\$ .85$

1.25

2.00

1.35

1.35
50

$\$ 2.00$

3.00

4.75

3.25

3.25
100

$\$ 3.50$

5.00

8.00

5.50

5.50

Less than 300 sent postpaid.

300 and over sold at 1000 rate, shipped as directed, charges collect. 


\section{BLACKBERRIES}

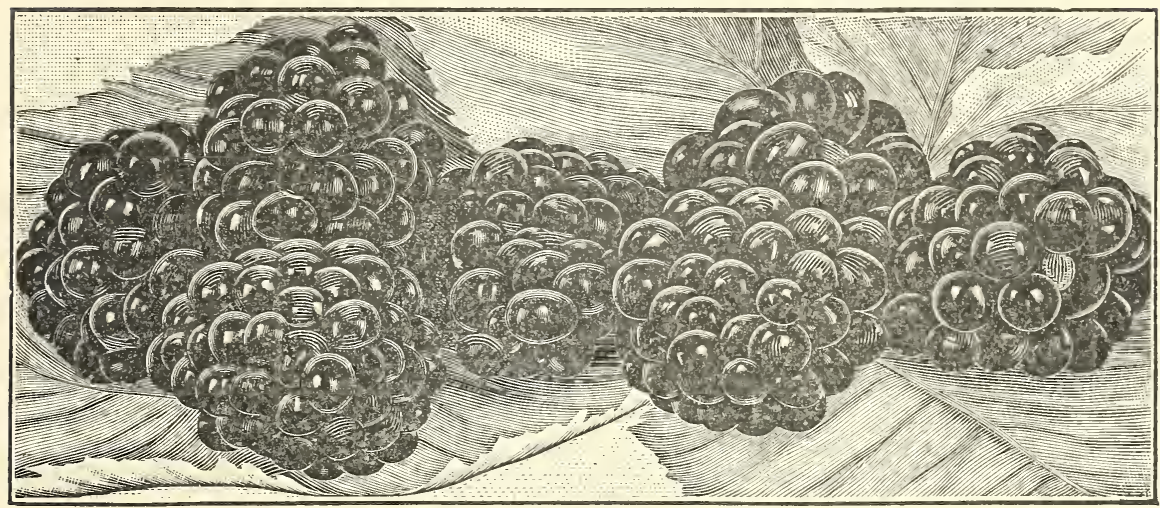

We grow and recommend the following varieties of Blackberry plants, becaue they are the best. There is no need of looking further. You can read of New varieties and of Great varieties, but either of the three mentioned below will stand alongside of the most elaborately advertised. These plants should be planted 6 feet apart each way and grown in hills. This makes them give you the biggest crop of the biggest berries with the least hand work. It takes 1200 plants per acre, at the above rate. If you wish you may plant them $5 \times 5$, this requires 1750 plants per acre. However, we believe the former will be most satisfactory to you.

BLOWERS-Possess the quadruple valuable qualities of large size, productiveness and absolute hardiness together with a prolonged season of fruiting. Just the thing for the gardener who has a Roadiside stand. On fertile soil the canes have often come ten to twelve feet high. Fruit is large, attractive and sweet.

ELDORADO-If you are looking for a time-proven, profitable and dependable Blackberry you will not be disappointed in the Eldorada, with its jet black extra fine berries that have long been considered exceptional for home use and known for their very few seeds. Due to the supreme health and vigor of Eldorado it requires no winter protection in even the coldest climates. In all, the finest quality of the very fine Blackberry plants we are offering.

MERSEREAU-A very fine berry . Used extensively as a substitute by many firmers for the old Wilson. Fruit is large glossy and firm, standing shipping very well. Has great productiveness and unusual freedom from orange rust.

PRICES

Blowers (Sucker plants)

Blowers, 2 year old

Eldorado (Suckers)

Eldorado, 2 year old

Mersereau (Sucker plants)

Less than 300 sent postpaid.

300 and over sold at 1000 rate, shipped as directed, charges collect.

Our plants called sucker plants are good one year old shoots that are fresh dug after your order is received and we guarantee them to grow. 


\section{RASPBERRY PLANTS}
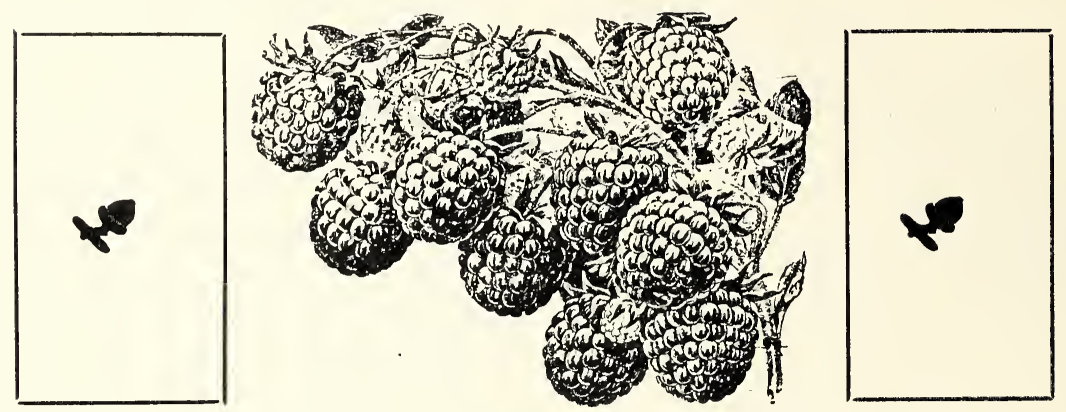

\section{ST. REGIS}

We offer only fresh-dug plants. No cold storage plants that were dug last fall or during the winter are shipped to our customers. Fresh lots dug daily. All our plants have passed State Inspection and when necessary have been inspected twice. (St. Regis) Another point is our plants are dug very carefully not to break the roots and we assure you satisfaction when given ordinary care. One setting is good for several years.

CULTURE-Plant the red or upright growing varieties in rows six feet apart and plants three feet apart in the rows, requiring 2420 plants per acre. In small garden, plant four feet apart each way and restrict to hill, permitting but three or four canes to remain in each hill. For field culture, the black cap varieties should be planted in rows seven feet apart and plants three feet apart down the row. Sucker plants should be trimmed back to within three inches of the ground three weeks after planting.

\section{THREE LEADING RED VARIETIES}

WELSH-A mid-season variety producing berries of extra large size, good, bright crimson color and very sweet. The finest in quality of any offered, but is not firm enough to ship well a long distance. The canes are vigorous, hardy and productive. The best for the home garden. Prices bottom of next page. 
CUTHBERT-The best Red Raspberry for commercial purpose. A variety that can be depended upon for a good crop of fine fruit in practically all sections of the country. For hardy, vigorous bushes plant in a sandy loam. Berries retain their brightness long after being picked. A wonderful berry for long distance shipping. PRICES: Bottom page.

ST. REGIS - (Most popular red everbearing) Not only raspberries, but berries 'of the very highest grade-in size, in brilliant crimson color, in firmness and flavor. Ripens with the earliest and continues on young canes until autumn, starting to produce about 80 days after planting. It succeeds on all soils, light or heavy. Canes absolutely hardy, producing large quantities of delicious fruit. The most widely planted variety for the market garden.

\section{TWO LEADING BLACK CAP VARIETIES}

CUMBERLAND_Produces large jet black fruit, firm, and of excellent quality; sweet and ripening in mid-season and continuing for two weeks. Stands long shipments well. Bush healthy and vigorous.

PLUM FARMER-Is considered by most growers to be the best early black cap variety. Strong, vigorous, upright grower, producing the largest of all Black Raspberries. Good for both home and market.

\section{LUCRETIA DEWBERRY}

This is the standard and best dewberry. Extremely hardy and very productive. It ripens in advance of the earliest blackberry and equals in size the best varieties of its near relation. The vines are of slender trailing habit, and succeed upon soils (even very sandy) and produce a sparkling jet black, large berry, of high quality and very firm. Ships well, keeps well, and sells well.

If to be stalked, plant in rows four feet apart each way; if to be mulched, plant in rows six feet apart and plants three feet apart in the rows. Good strong tip plants.

\section{PRICES}

Welsh (Suckers)

Welsh (Transplanted)

Cuthbert, (Suckers)

St. Regis (Suckers)

St. Regis (Transplanted)

Cumberland (Tips)

Plum Farmer (Tips)

Dewberry (Tip plants) 300 or less shipped Postpaid.

300 and over sold at 1000 rate, shipped as directed, charges collect.

We sell the above listed plants in any amount up to 50,000 of a variety. Write us for special prices on quantity lot, stating amount you can use.

$\begin{array}{cccr}12 & 50 & 100 & 1000 \\ \$ .45 & 1.35 & \$ 2.25 & \$ 16.50 \\ .85 & 2.25 & 4.00 & \\ .50 & 1.50 & 2.50 & 18.50 \\ .45 & 1.35 & 2.25 & 16.50 \\ .85 & 2.25 & 4.00 & \\ .60 & 1.75 & 2.75 & 20.00 \\ .50 & 1.50 & 2.50 & 18.50 \\ .40 & 1.00 & 1.75 & 10.00\end{array}$

1000 


\section{STRAWBERRIES}

BIG JOE-(Perfect) This is a splendid variety that is being extensively grown in this country, and in our judgement it is second to none, all points considered. It has been grown in this section several years, each year netting as much or more money per acre than any other variety grown for commercial purposes. It is wonderfully productive of extra large good quality berries that bring top prices in market. It is a larger berry than the Chesapeake, ripens a few days earlier and has as fine appearance as any strawberry that we have ever seen. It is uniform, well colored and firm enough for distant shipment. The plants are strong growers and good plant maker with luxuriant light green foliage. You can make no mistake by including the Big Joe in your order.

LUPTON-(Perfect) A good late variety. Plants are healthy, strong, growers, making enough plants for a good fruiting row. Foliage dark green. Very productive of beautiful brilliant red berries that resemble Chesapeake in shape. Ripens perfect and excellent shipper.

CAMPBELLS EARLY-(Perfect).Its foliage is large and of a beautiful dark green. In the production of fruit and plants it is a marvel. Its berries are large and beautifully formed. Color a deep glossy red, a trifle lighter than others. The meat is solid and rich. The berries are excellent shippers and splendid keepers. The calyx is a bright green, seeds yellow. This is a strong bisexual variety and has a long 'blooming season.

KELLOGG'S PRIZE-(Imp.) This is a pistilate variety and ripens late. Very productive of high quality bright glossy red berries, with yellow seeds, slightly imbedded, which makes a beautiful appearance when packed for market. Plant Kellogg's Prize with Big Joe and you will have a winner.

PREMIER or HOWARD 17-(Perfect) In our judgement this is the most perfect early variety to date. In fact, it is in a class by itself, having all the desirable qualities necessary to constitute an ideal extra early variety. Thrives on practically all soils. Has dark green foliage coming to a medium height and shows no sign of disease. Berries are large, beautiful deep red, with all the quality one would desire in strawberries. Too much cannot be said of this wonderful berry. The leading and best known of the early varieties. A great money maker for the market gardener or the man with a road stand. 


\section{MASTODON}

THE WONDERFUL NEW EVERBEARING STRAWBERRY

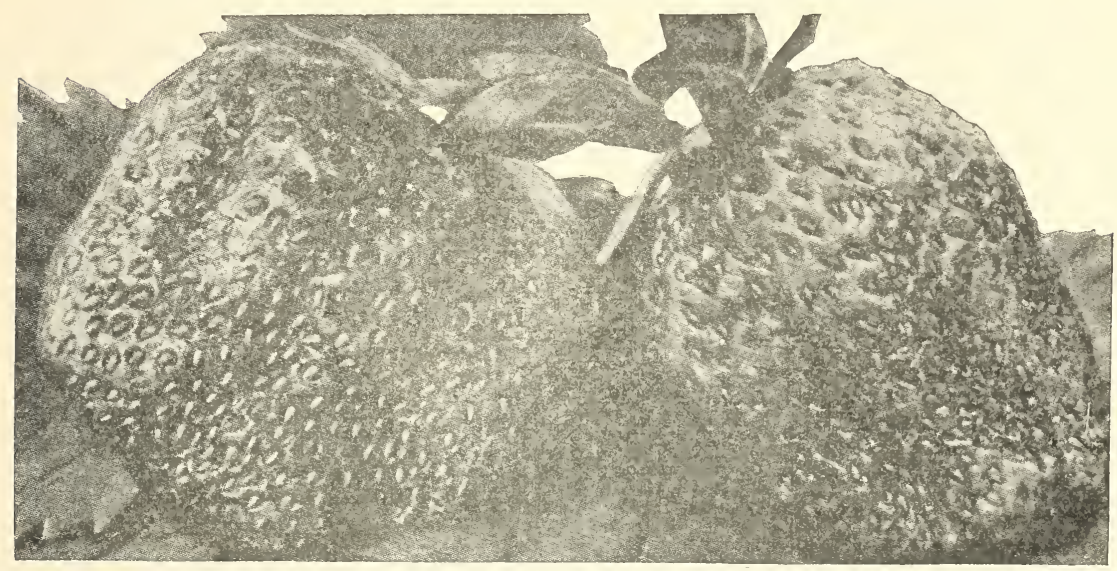

This great strawberry found in Indiana a few years ago, has stood tests in practically every section of the United States the last couple of seasons. It is now widely distributed and favorable reports come from experiment stations in various states where the berry has been tried.

The fruit is almost double in size of the ordinary everbearers. Produces a heavy crop in the spring and another in late summer and early fall. Will produce a good crop this fall if planted in early spring.

It is truly the largest, most delicious and heaviest yielding of all everbearing sorts. It outyields some of the finest June bearing sorts during their season and continues to bear, throughout summer and fall, berries of amazing size and surpassing quality. For best results (though this is not essential), plants should be disbudded up to July 1st. They will then bear banner crops beginning early in August and continue to produce heavy crops of delicious berries right up until severe treezing weather.

We have our own MASTODON plants from stock purchased direct from the originator and guaranteed true to name.

As the quantity we have is small in comparison to the orders which . we will receive, we advise placing your order immediately if this variety is wanted.

PRICES: Following page. Write for special prices on large lots stating amount you can use. 


\section{Strawberry Culture and Price List}

For hill culture, rows should be either 24,30 or 36 inches, and plants set 12 inches apart down the row.

For matted row system rows should be either 42 or 48 inches and plants set 18 to 24 inches in row.

An important point when planting Strawberry plants is to get your plants in the ground the same depth as they grew in the original bed, and to pack the dirt firmly around the roots. We have found the two following methods most practical. If plants are to be set with two-horse transplanter, we use light marker attached to transplanter, setting the plants level with the surface, 'within a few days after planting we sow fertilizer down the rows at the rate of $400 \mathrm{lbs}$. per acre, following with the cultivator, being very careful not to disturb the roots of the plants, also not to cover up the crows or heart of the plants. If plants are to be set with trawl, we use a one-horse plow to make a furrow, sow fertilizer down the furrow at the rate of $400 \mathrm{lbs}$. per acre, make a sharp list with one-horse plow, then strike list down nearly level with the field with light drag, or board. Drag and set plants immediately.

We strongly advise very early spring planting, as plants set early get a good start before the hoty dry weather strikes them and are much more apt to grow and make a good fruiting row than those set late in the season.

Planting Season April 1st to May 15th.

\section{PRICES}

Big Joe (Perfect late variety)

Campbell's Early (Perfect)

Kellog's Prize (Imp.)

Lupton (Perfect, Late)

Premier (Perfect)

MASTODON
50

$\$ .65$

.60

.65

.50

.50

1.00
100

$\$ 1.00$

.90

1.00

.90

.90

1.50
500

1000

$\$ 5.00$

4.75

5.00

4.75

4.75

8.50

Postpaid, 500 or less; more than 500 charges collect.

WE GUARANTEE All our plants, roots and vines to be true to name, healthy and reach you in first class condition. They must grow if you plant immediately upon arrival and water a little if necessary. If they don't we will on satisfactory proof refill your order, free of charge. 


\title{
TOMATO PLANTS
}

\author{
(Ready About May 10th)
}

EARLIANA-Early, good size and quite smooth. A very fine tomato for market; scarlet red color. An excellent early tomato for home use. PRICES: dozen, 25c; $100, \$ 1.00 ; 500, \$ 4.00$; postpaid; $1000, \$ 6.00$, by express collect. Transplanted Plants: $40 \mathrm{c}$ per dozen; $\$ 2.50$ per 100 , postpaid; $1000, \$ 20.00$, sent as directed, charges collect.

MARGLOBE - The Great New Tomato introduced by the U. S. Department of Agriculture through the efforts of Dr. Fred J. Pritchard, of the Bureau of Plant Industry is the last word in Tomatoes.

Never before has a hybrid of such great promise been brought to our notice. Its spreading habits of growth enable it to bear large, perfect globe-shaped fruit in great abundance. In color it is a most beautiful scarlet, ripening well up to the stem. Its eating qualities, likewise, are very much superior to most of the common varieties.

Hot Bed plants ready May 10th or 15th as follows: Dozen 30c; 100, $\$ 1.50 ; 500, \$ 6.00$ sent postpaid; $\$ 10.00$ per 1000 collect, sent as directed.

Extra Heavy Transplanted (spotted) plants as follows: Dozen 65c; $100, \$ 3.25 ; 500, \$ 15.00$ postpaid; $\$ 28.00$ per 1000 collect sent as directed.

\section{CABBAGE PLANTS}

\section{(Ready About April 12th)}

JERSEY WAKEFIELD. It is a very solid early cabbage and it has a very few outer leaves. Can be set very early. It will mature nice, large head in 75 to 80 days. PRICES: 25, 30c; 100, 85c; 500, \$2.50 postpaid; $\$ 4.00$ per 1000 collect, sent as directed.

COPENHAGEN MARKET. A fine, large, early, round-head cabbage. It will stand a long time without bursting and easy to grow. to 10 pounds. Short stem, heads almost on the ground and can be set closer than other varieties. They should be set out in every garden. Try them. PRICES: 25,40 c; $100, \$ 1.00 ; 500 \$ 3.00$, postpaid; $\$ 5.00$ per 1000 collect, sent as directed.

\section{EGG PLANT PLANTS}

NEW YORK IMPROVED LARGE PURPLE-Fruit large, fine and free from thorns. Matures in 130 days. Skin rich purple, flesh white and of good flavor. We can highly recommend our carefully selected strain of this egg plant to everyone. PRICES: Same as Black Beauty. Transplanted plants only.

BLACK BEAUTY-Is very early, in fact the earliest of good market variety. It grows a good size fruit for market. Average weight, two to three pounds. Bears its fruit close to main stem. PRICE: Dozen 50c; 100, $\$ 3.00$ postpaid. Spotted or transplanted plants. (Ready about May 25th). 


\section{SWEET POTATOES}

CULTURE Plants should not be set until the soil becomes warm and weather mild. We find they do best if set in a sandy loam, altho they do well on quite heavy soil also. Set plants in either hills or on ridges about 6 inches in height, the rows being about 3 feet apart and plants 18 inches apart down the row. After preparing the ground and marking out the rows put a small handful of fertilizer (rich in potash) and well mixed in each hill. Of course, a small shovelful of compost or manure will answer the purpose just as well. If, while setting the plants the soil is dry, always be sure to put a little water in the hole with the plant, this insures it getting a good start.

Follow with thorough clean culture. Using a cultivator with vine turners, if in field and always bank the soil towards the plants. You can allow the vines to root on the top of the ridge, if you wish, as it seems to do no harm, but makes digging harder.

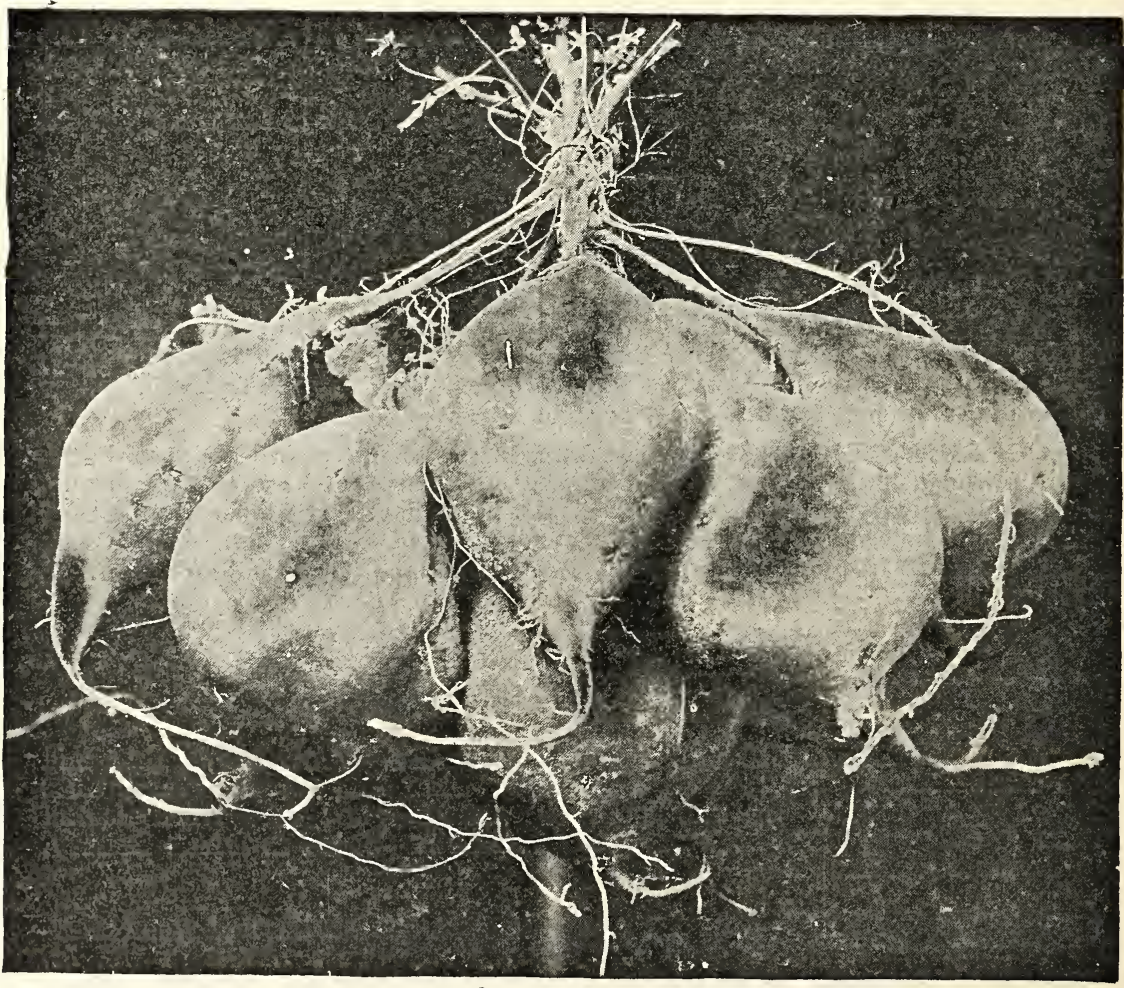

OUR LEADER (THE JERSEY YELLOW) 


\section{DIGGING AND STORING}

Dig in dry weather if possible, and allow to dry several hours in field. Put immediately in storage if to be kept over winter. Moving afterwards even from place to place in the same room will sometimes cause them to rot. A dry cellar with a tove or heater, where the temperature can be kept about 50 to 60 degrees and air dry is one of the best places to keep sweet potatoes, although for large quantities storehouses are often built above ground. It is usual to leave an air space of four inches or more under the bins or boxes in which they are stored.

THE JERSEY YELLOW-This seems to be the preferred name for the sweet potato grown mainly in New Jersey. Our Vineland Fancy Strain has for years been carefully selected from the best Jersey Yellow seed, having a smooth skin, good form, color and general appearance as well as productiveness and keeping qualities.

BIG STEM JERSEY-Another very good variety. A very rapid grower and heavy yielder of the Jersey Yellow type. PRICE: For Big Stem Jersey and Jersey Yellows; Selected disease-free seed Potatoes, per peck $\$ 1.00$ postpaid; per bushel $\$ 2.25$ sent as directed, charges collect; 5 bushels and over $\$ 2.10$ per bushel.

First class plants (Sprouts) sent postpaid: $\$ 1.00$ per $100 ; 500, \$ 2.25$; $1000, \$ 2.50$, larger lots sent as directed, charges collect.

\section{(Planting season May 15th to June 15th)}

THE JERSEY REDS-A fine potato. The best of all sweet potatoes for table use. Also good for the market grower. Is a heavy yielder of well shaped potatoes of a very attractive color.

Selected disease-free seed Potatoes, $\$ 1.25$ per peck postpaid; $\$ 2.75$ per bushel shipped as directed, charges collect, over 5 bushels $\$ 2.50$ per bushel.

Good strong plants: $\$ 1.25$ per $100 ; 2.50$ per $500 ; \$ 3.75$ per 1000 , postpaid.

(Planting season same as for Yellows)

We advise the small grower to buy plants instead of tubers.

We sell seed sweet potatoes and plants in large quantities. Write us for special prices, stating amount you can use.

\section{YAMS (White or Red)}

This potato is most commonly grown in the South, but it has proven very satisfactory in this locality and also further north. The tuber comes much larger than the ordinary sweet potato, and matures much earlier.

This is an important factor to the gardener wanting Sweets for early market or road stands. Keeps over the winter months as good as the ordinary sweet potato. Price, same as the Jersey Red Sweet Potato.

\section{A SPECIAL INTRODUCTORY OFFER}

100 Jersey Yellow

100 Jersey Reds

25 Yams
First-class disease free plants, sent postpaid for $\$ 2.00$. 


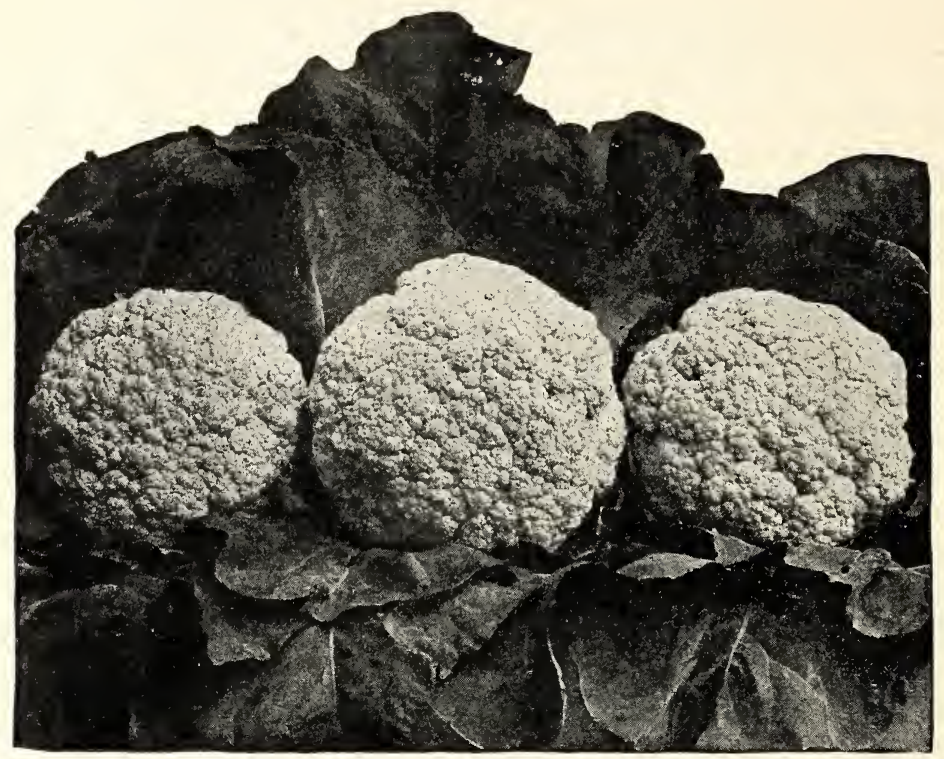

THE SNOWBALL CAULIFLOWER

April 15th to Aug. 12th

SNOWBALL-This is the most popular of all cauliflower. One of the best for home or market gardeners. Snowball Cauliflower can be planted for early or late and it will make a fine large head. Another advantage of planting Snowball Cauliflower is that the plants can be set closer in the row than other varieties. Early field grown plants ready about May 1st. Late field grown plants ready about July' 1st. PRICES: dozen, 20c; $100, \$ 1.00 ; 500, \$ 4.00$, postpaid. $\$ 7.00$ per 1000 , collect.

NEW CENTURY CAULIFLOWER-New Century Cauliflower is about the same size as Snowball, and it has a fine flavor and is, a very good keeper. PRICES: Same as Snowball. Field grown plants ready May 25 th.

\section{BRUSSELS SPROUT PLANTS}

BRUSSELS SPROUTS-Small heads or knobs along the stem. They are better than cabbage, may be boiled like cabbage or cooked like cauliflower. Ready for use in 125 days from time you set out the plants. Be sure to try them. PRICES: Same as cauliflower.

\section{PEPPER PLANTS}

BULL NOSE or CHINESE GIANTS-Both are very good large sweet Peppers. Flesh is thick and meaty. Immensely productive varieties, they sell well in the market and are fine for home use. PRICES: Dozen 25c; $100,90 c ; 500, \$ 3.00$, postpaid; $1000, \$ 4.25$, shipped as directed, collect. 


\section{Some Good Home Collections at Special Prices}

12 St. Regis, Sucker plants

12 Eldorado, Sucker plants

12 Cumberland, Tip plants

12 Lucretia Dewberry

\section{Total Value}

12 Cuthbert, Sucker plants

12 Cumberland, Tip plants

12 Eldorada, Sucker plants

6 Concord Grape 2 year, No. 1

$$
\text { Total Value }
$$

6 Concord Gnape, 2 year, No. 1

6 Niagara Grape, 2 year, No. 1

50 Mastodon Strawberry,

12 Rhubarb, 2 year, No. 1

12 Horseradish, roots
$\$ .45$

.50

.60

. 40 Will send postpaid to your address this Collection for $\$ 1.50$.

$\$ 1.95$

$\$ .50$

.60

.50

1.38

$\$ 2.98$

Will send postpaid to your address this Collection for $\$ 2.50$.

$\$ 1.38$

.98

1.00

.85

.45
Will send postpaid to your address this Collection for $\$ 4.00$. (A real buy). 


\section{L. \& F . DONDERO VINELAND, N. J,}

Date

For amount enclosed \$

send by

Mail, Express or Freight

To

Write Full Name Plainly

Street and No.

R. F. D. No.

Post Office

State

Express or Freight Office

If different than P. $O$.

About Date Wanted

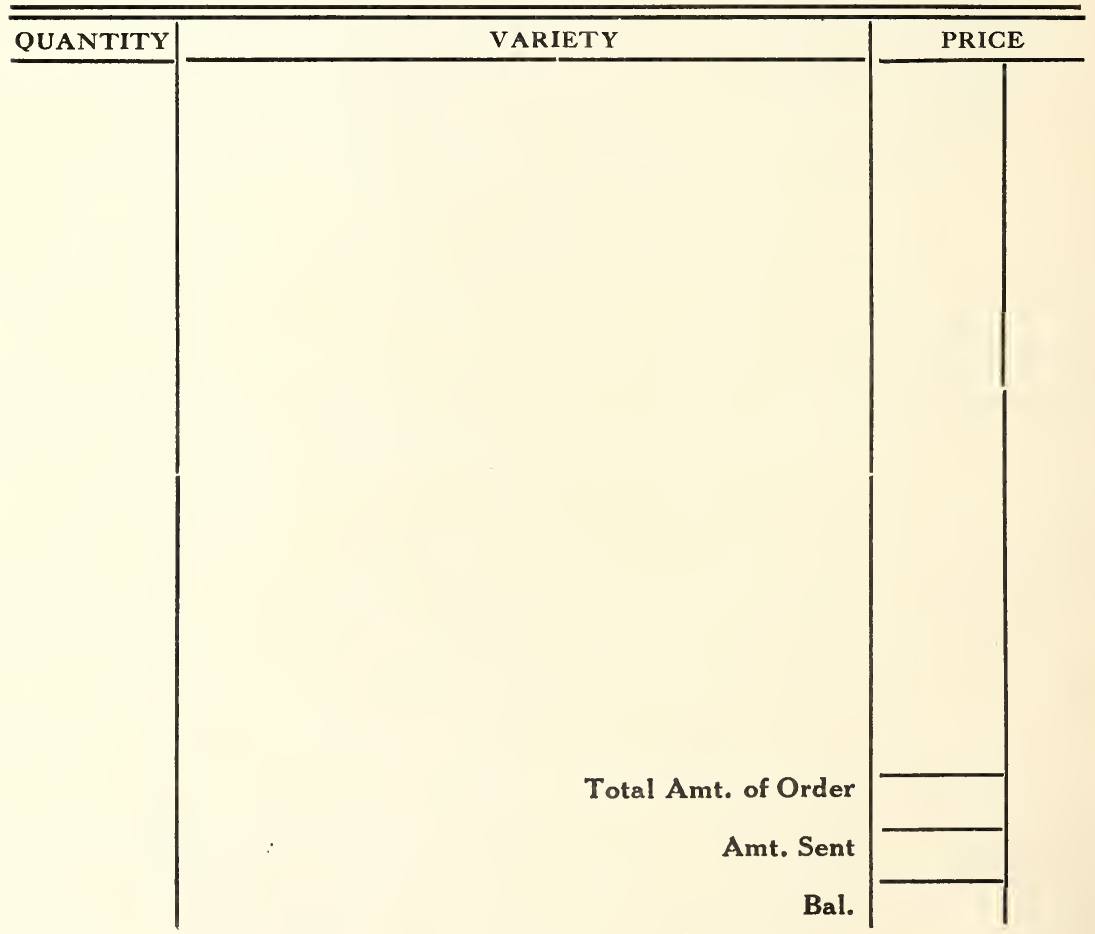




\section{RHUBARB}

GENUINE VICTORIA rhubarb grown by Dondero in our own field, especially adopted to the growing of fine roots.

A money making crop that comes early in the Spring (even before strawberries) when we all can use a few dollars to good advantage. A crop that you have sure sale for in the market or on Road side stands.

The VICTORIA is the only variety grown by us and the best variety known, producing large and tender stalks that are just the thing for pies or canning or fresh table sauce. Yields abundantly and much earlier than the old common sorts. Just the money maker you want to plant in the idle acres you have. Rhubarb requires very little attention and is planted like asparagus.

Plant in trenches 4 feet apart laying roots 2 feet apart and cover with good top-soil. Planted this way it takes about 5500 plants per acre. Two dozen or 50 is enough for the average family.

Prices bottom of page.

Good, strong, healthy 2 year old roots

\section{PRICES}

Victoria Rhubarb

Victoria No. 2, Rhubarb

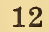

$85 \mathrm{c}$

50
50

$\$ 2.75$

1.75
100

$\$ 4.00$

3.00
1000

$\$ 30.00$

18.00

Less than 300 sent postpaid; 300 or more at 1000 rate, collect, as directed.

A SPECIAL GUARANTEE OFFER. Place your order with us for No. 1 Victoria Rhubarb roots. We will send them postpaid in lots up to 300 . When you receive these roots inspect them carefully and if they are not the nicest, cleanest and best Rhubarb roots you ever purchased, lea us know and we will cheerfully refund your money. How is that

\section{Horseradish Roots}

MALINER KREN Of very strong growth. A new variety that makes an enormous yield and is so early that it may be marketed before the common kind is ready. Cuttings planted in April will produce fine large radish for grating the first of October. If left in ground until Spring, grows to great size and produces as much as four tons to the acre. It is as white as snow when dressed. Entirely free from all diseases and grows on practically all soils. Plant with largest end up covering over about 1 inch with top-soil, in rows 4 feet apart and roots to be about 18 to 24 inches apart in the row. You will have no trouble growing a good crop with our roots. We guarantee.

\section{PRICES}

Horseradish Roots, 6 inch cuttings
12

45
50

1.00 


\section{HEDGE PLANTS \\ Barberry Thunbergie}

The Wonderful new Hedge plant that excells as an informal hedge. Its low dense horizontal growth and graceful branching habit make it most beautiful. Has a bright green foliage very early in the spring and this changes to beautiful shades of orange and red in the Fall of the year; and the attractive red berries which hang on all winter and are sometimes retained until the plants leaf out the following spring. Good strong plants about 1 foot high. PRICES: 25c each; $\$ 2.50$ per dozen, postpaid; $\$ 10.00$ per 100 Express collect. A few Extra Heavy 35c each; $\$ 3.50$ per dozen, postpaid.

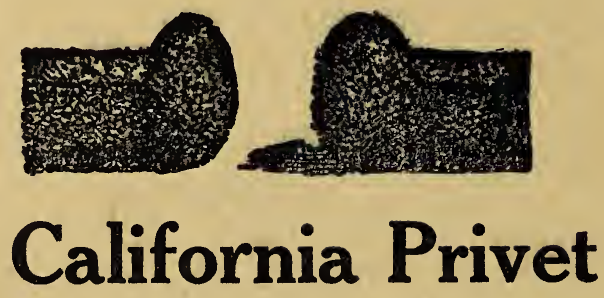

For many years California Privet has been recognized as the best plant for hedge purposes, as it is remarkable for its beautiful dark green, glossy foliage, its quick, strong and symmetrical growth, its freedom from insects and scale and its ability to withstand pruning and 'trimming into any desired shape.

We have been for many years the leading growers in this section and our stock cannot be surpassed anywhere. It is strong, thrifty and in the best shape for transplanting, each one being a specimen plant.

We offer at this time first class one and two year old plants as follows:

PRICES

12 to 18 inches

18 to 24 inches

2 to 3 feet

10
$\$ .95$
1.15
1.45

100
$\$ 3.00$
4.00
6.00

500

$\$ 10.00$

15.00

18.00

1000

$\$ 18.00$

22.00

30.00

Lots of 100 or less will be sent by parcel post, prepaid. Larger lots, as directed, charges collect. Let us quote on quantity lot.

\section{YOUR CORRESPONDENCE SOLICITED}

\section{L. and F. DONDERO}

\section{DELSEA DRIVE}

